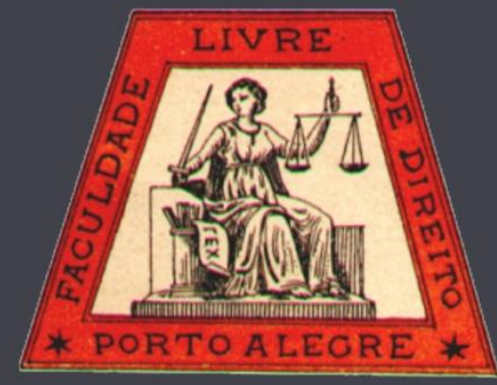

\title{
Sistemas de autorregulamentação da publicidade: um quadro comparativo entre países
}

Selfregulation systems advertising: a worldwide comparative study

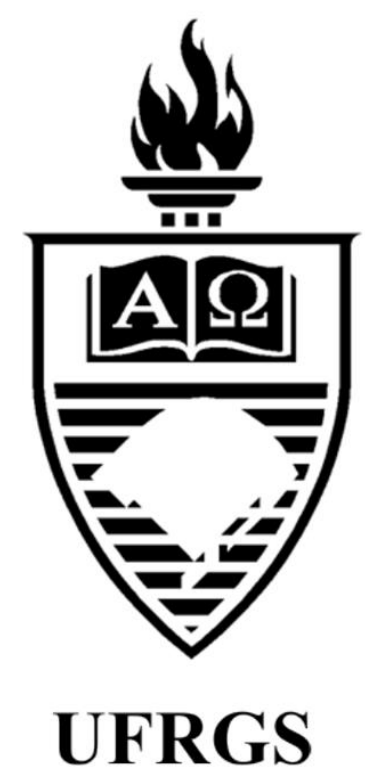

Adalberto de Souza Pasqualotto

Pontifícia Universidade Católica do Rio Grande do Sul

Luiza Kremer Cauduro

Pontifícia Universidade Católica do Rio Grande do Sul

Revista da Faculdade de Direito da UFRGS

ISSN: 0104-6594 Site http://seer.ufrgs.br/revfacdir

Faculdade de Direito da UFRGS - Rua Riachuelo, 1317 - Centro - Porto Alegre - RS - Brasil

CEP - 90010-271 - Telefone: +55 5133083118 - Site http://www.ufrgs.br/direito/ 


\title{
Sistemas de autorregulamentação da publicidade: um quadro comparativo entre países
}

\author{
Selfregulation systems advertising: a worldwide comparative study
}

Adalberto de Souza Pasqualotto*

Luiza Kremer Cauduro**

\section{REFERÊNCIA}

CAUDURO, Luiza Kremer; PASQUALOTTO, Adalberto de Souza. Sistemas de autorregulamentação da publicidade: um quadro comparativo entre países. Revista da Faculdade de Direito da UFRGS, Porto Alegre, n. 35, vol. esp., p. 207230, dez. 2016.

\section{RESUMO}

O presente artigo tem como objetivo a análise dos sistemas regulatórios da publicidade no Brasil e em onze países estrangeiros, de molde a ser possível comparar os modelos e, nesse sentido, concluir qual forma de regulação é mais adequada e eficaz para realizar o controle das mensagens publicitárias. Para tanto, a legislação do Brasil e de países estrangeiros, bem como diversas doutrinas reconhecidas são utilizadas, a fim de se obter um estudo bastante qualificado e consistente. $\mathrm{O}$ trabalho em tela está dividido em dois capítulos. O primeiro capítulo trata sobre as formas de controle da publicidade, delimitando as características do modelo estatal e do privado. O segundo capítulo, por sua vez, aborda especificamente a respeito dos modelos de autorregulamentação da atividade publicitária, descrevendo o modelo regulatório privado dos doze países selecionados, delimitando as características e particularidades de cada órgão.

PALAVRAS-CHAVE

Publicidade. Sistemas de Regulamentação.

\section{ABSTRACT}

This article aims to analyze the regulatory systems of advertising in Brazil and in eleven foreign countries in order to be able to compare models and, accordingly, conclude what form of regulation is more appropriate and efficient to perform control messages advertising. Therefore, the laws of Brazil and foreign countries, as well as several recognized doctrines are used in order to obtain a highly qualified and consistent study. The work screen is divided into two chapters. The first chapter deals with the forms of advertising control, defining the characteristics of the model state and private. The second chapter, in turn, addresses specifically about the self-regulation models of advertising activity, describing the private regulatory model of the twelve selected countries, defining the characteristics and peculiarities of each organ.

\section{KEYWORDS}

Advertising. Regulatory systems. Self-regulation.

Autorregulamentação.

\section{SUMÁRIO}

Introdução. Introdução. 1. Modelos de controle da publicidade. 1.1. Controle estatal. 1.2. Autorregulamentação. 2. Modelos de autorregulamentação. 2.1. Modelo brasileiro. 2.2. Aspectos comparados. 2.2.1. Alemanha. 2.2.2. Argentina. 2.2.3. Austrália. 2.2.4. Canadá. 2.2.5. Chile. 2.2.6. Espanha. 2.2.7. Estados Unidos. 2.2.8. Itália. 2.2.9. França. 2.2.10. Portugal. 2.2.11. Reino Unido. Conclusão. Referências.

\footnotetext{
* Professor titular da Pontifícia Universidade Católica do Rio Grande do Sul - PUCRS. Doutor em Direito (Universidade Federal do Rio Grande do Sul - UFRGS, 2006). Mestre em Direito (Universidade Federal do Rio Grande do Sul - UFRGS, 1992). Graduado em Direito (Pontifícia Universidade Católica do Rio Grande do Sul - PUCRS, 1972).

** Especialista em Direito Processual Civil e em Direito do Consumidor (Universidade Federal do Rio Grande do Sul UFRGS). Graduada em Direito (Pontifícia Universidade Católica do Rio Grande do Sul - PUCRS, 2013). Advogada.
} 


\section{INTRODUÇÃO}

$\mathrm{O}$ presente artigo jurídico tem como objetivo abordar os sistemas de autorregulamentação da publicidade no Brasil e em países estrangeiros, de molde a ser possível obter uma visão ampla dos modelos e, nesse sentido, concluir qual forma de autorregulamentação é mais adequada e eficaz para realizar o controle das mensagens publicitárias.

Em virtude da presença de uma sociedade de consumo de massa nos dias atuais, a atividade publicitária passou a ser incansável na busca pela atenção dos consumidores, eis que é a técnica utilizada por empresas e organizações para fornecer informações, desenvolver atitudes e influenciar o público a seu favor.

Assim sendo, diante da dimensão do impacto que os agentes publicitários podem ter sobre os consumidores, o controle da publicidade passou a ser indispensável para a estipulação de regras e parâmetros de conduta, para fins de efetuar a proteção dos interesses dos indivíduos.

A presente exposição acadêmica visa analisar as formas de controle da publicidade, através do modelo público e privado e, em especial, averiguar quais são os órgãos responsáveis pela autorregulamentação da atividade publicitária em doze países diferentes, bem como quais são as suas formas de atuação, de molde a averiguar a real eficácia dos mecanismos.

Após a análise dos dados, intenciona-se que seja possível ter conhecimento de como é exercida a autorregulação da publicidade nos doze países selecionados, Alemanha, Argentina, Austrália, Brasil, Canadá, Chile, Espanha, Estados Unidos, França, Itália, Portugal e Reino Unido, para fins de ser possível concluir em qual

\footnotetext{
${ }^{1}$ DINIZ, Catarina Fernandes. A influência dos estímulos não-consciencializados no comportamento do consumidor. Tese para a Licenciatura em Comunicação Empresarial, ISCEM, Lisboa, 1999. p. 15.
}

região a atividade publicitária é mais bem controlada. Os referidos países foram escolhidos de molde a se obter uma visão global a respeito do controle da publicidade realizado pelos órgãos privados.

Para o efeito da presente exposição, o trabalho foi dividido em dois capítulos. O primeiro capítulo trata sobre as formas de controle da publicidade, delimitando as características do modelo estatal e do privado. O segundo capítulo, por sua vez, aborda especificamente a respeito dos modelos de autorregulamentação da atividade publicitária, descrevendo o modelo regulatório privado dos doze países selecionados, delimitando as características e particularidades de cada órgão.

\section{MODELOS DE CONTROLE DA PUBLICIDADE}

Primeiramente, insta esclarecer o que é publicidade. Segundo Catarina Diniz ${ }^{1}$, é toda forma de comunicação que visa chamar a atenção do público para um bem ou serviço, com o fim de promover a sua aquisição.

A publicidade de consumo pode ser definida como um ato lícito, efetuado a expensas do fornecedor, que visa levar ao conhecimento do público consumidor uma imagem ou uma mensagem com um conteúdo informativo, com fins econômicos destinados a fomentar direta ou indiretamente a realização de negócios jurídicos de consumo. ${ }^{2}$

No dizer de Lucia Ancona Lopez de Magalhães, a publicidade

[...] pode ser conceituada como o meio de divulgação de produtos e serviços com a finalidade de incentivar o consumo. Trata-se do "par excellence" através do qual se leva ao conhecimento dos consumidores em
${ }^{2}$ MARTINEZ, Sergio Rodrigo. O ambiente conceitual da publicidade de consumo e de seu controle no Brasil. Revista de Direito do Consumidor, São Paulo, Revista dos Tribunais, n. 58, p. 223-255, abr./jun. 2006. p. 231. 
geral a existência de bens e serviços a serem examinados e eventualmente. ${ }^{3}$

A definição de publicidade pode ser encontrada no artigo $8^{\circ}$ do Código Brasileiro de Autorregulamentação Publicitária: "Publicidade comercial é toda atividade destinada a estimular o consumo de bens ou serviços, bem como promover instituições, conceitos ou ideais."4

Adalberto Pasqualotto leciona que a publicidade é contato social de consumo, fonte de obrigações autônoma, da mesma categoria dos atos existenciais ou das condutas sociais típicas, produzindo, contudo, os mesmos efeitos dos atos negociais. $^{5}$

Pasqualotto igualmente define que a publicidade

[...] é toda comunicação de entidades públicas ou privadas, inclusive as não personalizadas, feita através de qualquer meio, destinada a influenciar o público em favor, direta ou indiretamente, de produtos ou serviços, com ou sem finalidade lucrativa. ${ }^{6}$

Por sua vez, Armando Sant'Anna ${ }^{7}$ ensina que a publicidade é uma técnica de comunicação de massa, paga com a finalidade precípua de fornecer informações, desenvolver atitudes e provocar ações benéficas para os anunciantes, geralmente para vender produtos e serviços.

Paulo Vasconcelos Jacobina ${ }^{8}$ define que a publicidade é uma atividade empresarial realizada com o objetivo de ofertar um bem ou serviço a consumo, através de um meio de comunicação capaz de atingir, ainda que potencialmente, um

\footnotetext{
${ }^{3}$ DIAS, Lucia Ancona Lopez de Magalhães. Publicidade $e$ direito. 2. ed. São Paulo: Revista dos Tribunais, 2013.

${ }^{4}$ CÓDIGO Brasileiro de Autorregulamentação Publicitária. Disponível

em:

<http://www.conar.org.br/codigo/codigo.php>. Acesso em: 23 out. 2015.

${ }^{5}$ PASQUALOTTO, Adalberto. Os efeitos obrigacionais da publicidade no Código de Defesa do Consumidor. São Paulo: Revista dos Tribunais, 1997. p. 113.

${ }^{6}$ Ibid.
}

número indeterminado de pessoas, e veiculada a expensas do fornecedor.

Cláudia Lima Marques ${ }^{9}$ conceitua publicidade como toda a informação ou comunicação difundida com o fim direto ou indireto de promover junto aos consumidores a aquisição de um produto ou a utilização de um serviço, qualquer que seja o local ou meio de comunicação utilizado.

Dessa forma, a publicidade é o conjunto de atividades de comunicação de massa que informa o consumidor sobre a existência de produtos e serviços com o objetivo de fixar a marca ou promover estilos de vida, bem como estipular sua aquisição. ${ }^{10}$ Nesse sentido, a liberdade de fazer publicidade encontra proteção constitucional pelo princípio da liberdade de expressão, conforme estipulam os artigos $5^{\circ}$, IX, e 220, da Constituição Federal.

Diante do exposto, tendo em mente a conceituação da atividade publicitária, é imperioso salientar que, a atividade publicitária não é ilimitada e necessita de regulamentação, diante da dimensão do impacto que os agentes publicitários podem ter sobre os consumidores, de modo a permitir o controle das manifestações da publicidade e, de conseguinte, garantir a proteção dos interesses dos indivíduos.

Eliese Almeida consigna que no ambiente de mercado de consumo altamente competitivo, no qual cada qual quer mais apresentar seus produtos e serviço como os melhores e mais indispensáveis para o cotidiano das pessoas, abrese espaço para que se usem mecanismos de quase todas as formas de inserção e/ou destaque no

7 SANT'ANNA, Armando. Propaganda: teoria, técnica e prática. 3. ed. São Paulo, Pioneira, 1981. p. 76.

${ }^{8}$ JACOBINA, Paulo Vasconcelos. A publicidade no direito do consumidor. Rio de Janeiro: Forense, 2012. p. 11.

9 MARQUES, Cláudia Lima. Contratos no Código de Defesa do Consumidor. 3. ed. São Paulo: Revista dos Tribunais, 1998, p. 345.

${ }^{10}$ DIAS, Lucia Ancona Lopez de Magalhães. Publicidade e direito. 2. ed. São Paulo: Revista dos Tribunais, 2013. p. 33. 
mercado. Afirma a autora que a publicidade é, por excelência, o instrumento viabilizador dessa visibilidade objetivada por aqueles que têm produtos e serviços postos à disposição e desejam manter e ampliar sua fatia no meio em que exploram a atividade, ou para os que vão entrar no ramo de fornecimento de produtos ou serviços.

Nesse sentido, por passar a ser um sistema de persuasão que molda necessidades, gera desejos, seduz os consumidores, constituindo um verdadeiro instrumento de controle social, essencial ter ciência dos meios de regulamentação legal e autorregulamentar das mensagens publicitárias existentes, bem como quais são as suas formas de atuação e qual o grau de integração entre os órgãos, a fim de ser possível verificar a real efetividade dos mecanismos de proteção existentes.

Assim sendo, para melhor entender o tema em pauta - o sistema estatal de regulamentação e o de autorregulamentação da publicidade - é essencial ter em mente, preliminarmente, os conceitos de sistema legal de regulamentação e de autorregulamentação.

\subsection{Controle social}

Regulamentação da publicidade trata-se de um método de intervenção por parte dos governos, a fim de fazer com que os mercados funcionem mais efetivamente, assegurando, assim, ao consumidor, um fluxo adequado de informação. É um exercício pragmático para assegurar aos consumidores as decisões baseadas em informações.

\footnotetext{
${ }^{11}$ SCHMITT, Cristiano Heineck. A proteção do interesse do consumidor por meio da garantia à liberdade de concorrência. Revista dos Tribunais, São Paulo: Revista dos Tribunais, ano 98, v. 880, p. 9-32, fev. 2009. p. 16.

12 CRAVO, Daniela Copetti. A tutela do consumidor através da livre-concorrência: a busca por um efetivo direito de escolha. Revista Magister de Direito Empresarial, Concorrencial e do Consumidor, Porto Alegre, v. 49, p. 6681, fev./mar. 2013. p. 68.
}

Através de modernas técnicas de marketing, agregadas a uma intensa publicidade, reforçada por mecanismos de convencimento e de manipulação psíquica utilizados pelos agentes econômicos, há a criação de necessidades antes inexistentes, bem como representações ideais de situações de vida que induzem o consumidor a aceitá-las. Assim sendo, o consumidor passa a ter a sua manifestação de vontade fragilizada, já não mais determinando suas prioridades $\mathrm{e}$ necessidades. ${ }^{11}$

O direito da concorrência pode ser visto como um desenho de tutela aos consumidores de forma externa, macro, uma vez que visa assegurar a competitividade do mercado. A finalidade desse ramo do direito econômico é o bem-estar do consumidor. ${ }^{12}$

Nesse sentido, diante da vulnerabilidade diagnosticada, há a necessidade de proteção da liberdade de concorrência como garantia à proteção do interesse do consumidor. Pfeiffer bem define que "[...] a livre concorrência é condição necessária para o desenvolvimento econômico sustentável, uma vez que é através dela que o consumidor dispõe de maior variedade de produtos por preços mais baixos que o do monopólio". ${ }^{13}$

O sistema legal é aquele exclusivamente estatal, em contraposição ao controle autorregulamentar, no qual compete exclusivamente ao Estado regulamentar e controlar as mensagens comerciais, inexistindo qualquer participação de atores publicitários. ${ }^{14}$

Antônio Herman Vasconcellos e Benjamin ${ }^{15}$ menciona o referido sistema se trata

${ }^{13}$ PFEIFFER, Roberto Augusto Castellanos. Tutela coletiva da livre concorrência. Revista de Direito do Consumidor, São Paulo, Revista dos Tribunais, n. 49, p. 15-23, 2004. p. 15.

14 CARVAlHO, Diógenes Faria de. A proteção do consumidor-criança frente à publicidade no Brasil. Revista de Direito do Consumidor, São Paulo, Revista dos Tribunais, n. 94, p. 181-211, 2014. p. 185.

15 BENJAMIN, Antônio Herman Vasconcellos e. O controle jurídico da publicidade. Revista de Direito do 
de modelo de controle externo da publicidade, tendo como argumentos favoráveis a perícia técnica do Estado (contando com órgãos especializados), sua capacidade de observar o mercado e sua ampla gama de poderes e instrumentos, inclusive de coação. Como aspectos negativos do modelo estatal apontam-se, no entanto, a lentidão e o formalismo da atuação estatal e as dificuldades de acompanhamento e ajustamento às necessidades do mercado.

O modelo estatal pressupõe que nenhuma atividade de interesse social pode ficar sem a proteção do Estado, tendo como elemento teleológico a sua destinação à proteção dos consumidores. ${ }^{16}$

A respeito da necessidade de regulamentação da atividade publicitária, Niklas Luhmann ${ }^{17}$ se posiciona, expondo críticas com relação à publicidade comercial. $\mathrm{O}$ doutrinador afirma que a publicidade funciona, e o faz sob a forma de auto-organização da estupidez, sendo que o que ela pretende é manipular, e trabalha com dubiedades para conseguir que o pressuposto da manipulação que a acompanha fique firmemente estabelecido e, ainda, acrescenta que a atividade publicitária declara abertamente sua intenção, mas refina e esconde com frequência os meios que utiliza.

Em síntese, Luhmann sustenta que a publicidade trabalha com o autoengano do público, o qual, através do elogio, é levado a exercer uma aparente liberdade de escolha, para querer o que realmente não queria. Diz que, na publicidade, a estética prevalece sobre a informação, uma estética autossuficiente, que não

Consumidor, São Paulo, Revista dos Tribunais, n. 9, p. 2557, jan./mar. 1994. p. 51.

${ }^{16}$ MARTINEZ, Sergio Rodrigo. O ambiente conceitual da publicidade de consumo e de seu controle no Brasil. Revista de Direito do Consumidor, São Paulo, Revista dos Tribunais, n. 58, p. 223-255, abr./jun. 2006. p. 247.

${ }^{17}$ LUHMANN, Niklas. La realidad de los medios de massas. Tradução para espanhol de Javier Torres Nafarrate. Barcelona: Anthropos, México: Universidad Iberoamericana, 2007. p. 66. dá lugar a uma resposta positiva ou negativa sobre a mensagem. E acrescenta que outro recurso muito empregado pela atividade publicitária é a "opacidade", ou seja, o uso paradoxal da linguagem, de modo que ninguém se sente excluído da mensagem. ${ }^{18}$ Deixando claro, nesse sentido, sua posição contrária à publicidade e a necessidade de regulamentação de tal atividade.

Rizzatto Nunes ${ }^{19}$ igualmente se posiciona neste sentido, ao afirmar que a liberdade de criação e expressão da publicidade está limitada à ética que dá sustentação à lei, razão pela qual, argumenta que não se deve simplesmente oferecer uma opinião (elemento subjetivo), mas sim, sempre falar e apresentar a verdade objetiva do produto e do serviço e as maneiras de uso, consumo, suas limitações, os riscos para o consumidor, razão pela qual, conclui que os anúncios publicitários devem sofrer a mesma limitação.

Bruno Miragem ${ }^{20}$ se manifesta dizendo que a publicidade se distingue de modo decisivo das demais formas de expressão, sobretudo peã vinculação íntima da atividade publicitária a um fim eminentemente econômico. Acrescenta que, em razão disso, a publicidade encontra seu assento constitucional na livre iniciativa econômica, a qual deve harmonizar-se com a defesa do consumidor por mandamento constitucional do artigo 170 da Constituição Federal.

Eugênio Facchini Neto ${ }^{21}$ lembra que só se poderia admitir uma liberdade destituída de limites se o homem vivesse isolado. Entretanto, como a sua realidade é e sociedade, torna-se

${ }^{18}$ Ibid., p. 68.

19 NUNES, Rizzatto. Publicidade \& Consumo. Revista Jurídica Consulex, Rio de Janeiro, v. 15, n. 349, p. 24-27, jul. 2011. p. 27.

${ }^{20}$ MIRAGEM, Bruno. Direito do consumidor. São Paulo: Editora Revista dos Tribunais, 2008. p. 170.

${ }^{21}$ FACCHINI NETO, Eugênio. A função social do direito privado. Revista da Ajuris, Porto Alegre, n. 105, 2007, p. 154-155. 
indispensável que se compatibilize o exercício dessa liberdade com os demais integrantes do grande grupo. Enfatiza o autor que é exatamente nesse contexto que se faz necessária a atuação do Direito, de molde a estipular limitações à referida liberdade de expressão.

Igor Britto ${ }^{22}$, por sua vez, aduz que a liberdade de informação, expressão e comunicação, no contexto constitucional de 1988, não se relaciona com liberdade de fazer publicidade comercial, que nunca sofreu censura, em momento algum da história das conquistas de direitos no Brasil. Afirma que garantir ao discurso publicitário o fundamento da liberdade de expressão constitucional é uma aparente banalização dos direitos humanos.

James Siano $^{23}$, também se posiciona neste sentido, ao alegar que as garantias fundamentais da liberdade de manifestação do pensamento e expressão devem ser interpretadas de maneiras restritivas, pois, enquanto não exteriorizadas, são absolutamente livres e sem restrições, mas no momento em que se iniciam os atos de execução, com a finalidade de veicular a mensagem publicitária, uma gama de restrições deve ser observada, de molde a prevalecer o interesse coletivo, o direito, respeito e a dignidade.

Nesse sentido, é possível concluir que, sendo a publicidade primordialmente instrumento de persuasão para o consumo, é considerada parte integrante da atividade econômica e, enquanto tal, é constitucionalmente protegida pelas normas que regem a ordem econômica. Esta, elegendo o modo de produção capitalista, garante a livre iniciativa,

\footnotetext{
22 BRITTO, Igor Rodrigues. Liberdade de expressão comercial, só se for nos Estados Unidos. Revista Jurídica Consulex, Rio de Janeiro, v. 15, n. 349, p. 28-31, jul. 2011. p. 30.

${ }^{23}$ SIANO, James Alberto. A publicidade como forma de liberdade de expressão. Revista dos Juizados Especiais, São Paulo: Fiuza, ano 9, v. 33, p. 11-37, jul./set. 2004. p. 37.

24 NUNES JR., Vidal Serrano. Limites à publicidade comercial e proteção de direitos fundamentais. Revista de Direito Constitucional e Internacional, São Paulo: Revista dos Tribunais, ano 16, n. 63, abr./jun. 2008. p. 282.
}

mas a condiciona à busca da dignidade humana $\mathrm{e}$ da justiça social, devendo ser respeitados princípios gerais. $^{24}$

\subsection{Autorregulamentação}

Autorregulamentação, por sua vez, é o sistema exclusivamente privado, que corresponde ao controle interno da publicidade realizado pelo órgão privado e ligado ao setor publicitário. ${ }^{25}$

Valéria Chaise ${ }^{26}$ igualmente aponta as seguintes características fundamentais desse sistema: a) a existência de uma associação de empresários estabelecida segundo $\mathrm{o}$ direito privado e de livre adesão; b) a presença de regras éticas, a fim de estabelecer limites para as mensagens comerciais e, simultaneamente, evitar a arbitrariedade dos órgãos de controle; c) a criação de órgão de controle competente para fiscalizar a observância das regras fixadas; d) a competência para impor sanções aos infratores; e) a presença de poder de pressão para o cumprimento da sanção.

Letícia Lourenço Pavani aduz que

[...] o Código Brasileiro de Auto-Regulamentação Publicitária traça algumas diretrizes a serem observadas em relação à publicidade, dirigidas a anunciantes, agências de publicidade e veículos de divulgação, podendo ser utilizado como documento de referência e fonte subsidiária da legislação. ${ }^{27}$

Nesse sentido, Frisque Momberger ${ }^{28}$ aduz que autorregulamentação é o sistema de controle exclusivamente privado, no qual somente os

${ }^{25}$ CHAISE, Valéria Falcão. A publicidade em face do Código de Defesa do Consumidor. São Paulo: Saraiva, 2011. p. 25.

${ }^{26}$ Ibid., p. 25-26.

27 PAVANI, Letícia Lourenço. Publicidade de serviços sexuais e implicações no âmbito da dignidade da pessoa humana e da proteção à infância. Revista de Direito Social, São Paulo: Notadez, ano VIII, n. 30, p. 93-104, abr./jun. 2008. p. 99.

${ }^{28}$ MOMBERGER, Frisque Noemí. A publicidade dirigida às crianças e adolescentes: regulamentações e restrições. Porto Alegre: Memória Jurídica, 2002. p. 51. 
participantes é que ditam as suas normas, não havendo participação do Estado. O doutrinador menciona que as regras nesse sistema se aplicam no limite do pacto entre os que aderem ao autossistema de regulamentação, podendo servir como exemplos o CONAR e o Código de AutoRegulamentação da Publicidade.

Quanto à autorregulamentação, Floriano de Azevedo Marques Neto define que:

\begin{abstract}
Autorregulação é a forma de regulação que surge a partir do interesse dos atores econômicos atuantes num dado subsistema, buscando a preservação das condições de exploração econômica, o fechamento deste sistema a novos entrantes ou a anulação ou absorção das interferências externas, de origem estatal ou não. A autorregulamentação tem caráter quase exclusivamente de regulação econômica. Seu caráter de regulação social é nulo ou meramente residual. $^{29}$
\end{abstract}

No dizer de Mario Frota ${ }^{30}$, a autorregulamentação, portanto, inscreve-se, por um lado, nas preocupações de específica proteção das empresas em um mercado concorrencial e, por outro, de modo direto ou reflexo, na garantia oferecida aos consumidores de adoção de determinados comportamentos suscetíveis de se conformarem aos interesses e direitos que lhe são próprios.

\section{MODELOS AUTORREGULAMENTAÇÃO}

Inicialmente, insta esclarecer que, conforme antes elencado, com o fenômeno da massificação social, a publicidade gradativamente vem se afastando da informação, tendo como escopo incitar ao consumo. ${ }^{31}$

\footnotetext{
29 MARQUES NETO, Floriano Azevedo. Regulação econômica e suas modalidades. Revista de Direito Público da Economia, Belo Horizonte, ano 7, n. 28, p. 27-42, out./dez. 2009. p. 37.

30 FROTA, Mario. Auto-regulamentação: vantagens e desvantagens. Revista de Direito do Consumidor, São Paulo, Revista dos Tribunais, n. 4, p. 42-90, 1992. p. 43.
}

Nesse sentido, por passar a ser um sistema de persuasão e um verdadeiro instrumento de controle social, essencial ter ciência dos meios de regulamentação legal e autorregulamentar das mensagens publicitárias existentes, não só no Brasil, mas em oito países estrangeiros, quais sejam Alemanha, Argentina, Austrália, Canadá, Chile, Estados Unidos, França e Reino Unido, bem como quais são as suas formas de atuação e qual o grau de integração entre os órgãos, elencando os pontos positivos e negativos dos sistemas, a fim de ser possível verificar a real efetividade dos mecanismos de proteção existentes.

\subsection{Modelo brasileiro}

A autorregulamentação da publicidade no Brasil é realizada pelo Conselho Nacional de Autorregulamentação Publicitária ${ }^{32}$, o qual tem como objetivo principal impedir que a publicidade enganosa ou abusiva cause constrangimento ao consumidor ou a empresas e defender a liberdade de expressão comercial.

$O$ órgão autorregulamentador define que os preceitos básicos que definem a ética publicitária são que todo anúncio deve ser honesto $\mathrm{e}$ verdadeiro e respeitar as leis do país; ser preparado com o devido senso de responsabilidade social, evitando acentuar diferenciações sociais; deve ter presente a responsabilidade da cadeia de produção junto ao consumidor; respeitar o princípio da leal concorrência e deve respeitar a atividade publicitária e não desmerecer a confiança do público nos serviços que a publicidade presta.

31 BENJAMIN, Antônio Herman Vasconcellos e. O controle jurídico da publicidade. Revista de Direito do Consumidor, São Paulo: Revista dos Tribunais, n. 9, p. 2557, jan./mar. 1994. p. 27.

32 CONSELHO Nacional de Autorregulamentação Publicitária. Disponível em: <http://www.conar.org.br/>. Acesso em: 03 fev. 2016. 
O Conselho Nacional de Autorregulamentação Publicitária (CONAR) foi criado pelos agentes do mercado publicitário no final dos anos 70, com a finalidade de zelar pela liberdade de expressão comercial e pela ética na publicidade, defendendo, ao mesmo tempo, os interesses dos profissionais e dos consumidores. ${ }^{33}$

É a instituição privada que fiscaliza a ética na propaganda comercial veiculada no Brasil, norteando-se pelas disposições contidas no seu Código Brasileiro de Autorregulamentação Publicitária. Assim sendo, na hipótese de haver a veiculação de publicidade em violação às normas do seu Código Ético, o Conselho de Ética poderá aplicar as sanções de advertência ao anunciante e sua agência; recomendação de alteração ou correção do anúncio; recomendação aos veículos para que sustem a divulgação do anúncio; ou, por fim, a divulgação na mídia da posição do CONAR em relação ao anunciante. ${ }^{34}$

O sistema de autorregulamentação foi fundado como uma ONG encarregada de aplicar as disposições do Código Brasileiro de Autorregulamentação Publicitária. Desde a sua criação, o órgão já instaurou mais de 7 mil processos éticos e promoveu inúmeras conciliações entre associados em conflito. Jamais foi desrespeitado pelos veículos de comunicação e quando foi questionado perante a Justiça, saiuse vitorioso.

O CONAR está dividido em oito Câmaras, sediadas em São Paulo, Rio, Brasília, Porto Alegre e Recife e é formado por 180 conselheiros, entre efetivos e suplentes, recrutados entre profissionais de publicidade de todas as áreas e representantes da sociedade civil. Não participam do Conselho pessoas investidas em cargos públicos por nomeação ou eleições, bem como candidatos a cargo eletivo em qualquer nível,

\footnotetext{
${ }^{33}$ DIAS, Lucia Ancona Lopez de Magalhães. Publicidade $e$ direito. 2. ed. São Paulo: Revista dos Tribunais, 2013. p. 40. ${ }^{34}$ DIAS, Lucia Ancona Lopez de Magalhães. Publicidade e direito. 2. ed. São Paulo: Revista dos Tribunais, 2013. p. 41.
}

assim sendo, todos trabalham em regime voluntário.

É constituído por publicitários e profissionais de outras áreas, tratando-se uma organização não governamental que visa promover a liberdade de expressão publicitária e defender as prerrogativas constitucionais da propaganda comercial.

O CONAR foi criado para regrar a publicidade em face da própria publicidade, ou seja, os publicitários brasileiros estabeleceram regras de conduta entre si, tendo como base o princípio da lealdade da publicidade, para fins de se protegerem da concorrência desleal. ${ }^{35}$

Assim sendo, o controle privado exercido pelo CONAR não possui o caráter coercitivo da lei, porém, as suas recomendações são respeitadas e acatadas pelos profissionais da área. As normas, ademais, estão em harmonia com o texto do Código de Defesa do Consumidor e igualmente servem de subsídios para o aplicador do direito, uma vez que refletem os usos e costumes do mercado ou publicitário ${ }^{36}$.

Ainda, o órgão privado de regulamentação da publicidade igualmente visa atender as denúncias dos consumidores, autoridades, associados ou formuladas pelos integrantes da própria diretoria.

As reclamações são analisadas e posteriormente julgadas pelo Conselho de Ética, com total e plena garantia de direito de defesa aos responsáveis pelo anúncio e, na hipótese de restar comprovada a procedência, o CONAR recomenda a alteração ou suspensão da veiculação do anúncio.

Dessa forma, resta evidente que o órgão privado não exerce censura prévia das mensagens publicitárias, tendo em vista que apenas analisa as que estão sendo ou foram veiculadas. Nesse

35 RODRIGUES, Marcelo Abelha. Ensaio sobre a publicidade e o seu regime jurídico no direito brasileiro. Revista dos Tribunais, São Paulo: Revista dos Tribunais, ano 96 , v. 864, p. 20-44, out. 2007. p. 36.

${ }^{36}$ DIAS, op. cit., p. 41. 
sentido, anúncios que contenham infração flagrante ao Código têm sua sustação recomendada de forma liminar aos veículos de comunicação. O CONAR é capaz de adotar medida liminar de sustação no intervalo de algumas horas a partir do momento em que toma conhecimento da denúncia.

As vantagens que esse sistema apresenta são a rapidez, a gratuidade e o grande peso moral de suas decisões sobre os regulados. E, em relação ao Estado, a vantagem é que a não intervenção garantiria a disponibilidade para a execução de políticas em domínios carenciados, libertando meios estruturais para diferentes planos, projetos e programas. ${ }^{37}$

No entanto, a crítica que é feita em relação ao controle exclusivamente privado é pelas decisões do CONAR só obrigarem os signatários de tal sistema, ou seja, não há a vinculação dos agentes do mercado. Assim sendo, há a ausência de generalidade e coercitividade que a lei e os atos estatais possuem. ${ }^{38}$

Adalberto Pasqualotto afirma que a principal desvantagem da autorregulamentação publicitária é que as decisões do CONAR são de cumprimento espontâneo. Os estatutos da entidade não lhe outorgam nenhum poder coativo - e, de qualquer modo, esse poder sempre seria limitado, por se tratar de uma sociedade privada. ${ }^{39}$

O texto constitucional, em seu artigo $5^{\circ}$, II e $\mathrm{XX}$, retira do CONAR e, portanto, desse sistema de autorregulamentação, quaisquer poderes de império que obriguem os anunciantes e publicitários, bem como os veículos de difusão, a se sujeitarem às suas deliberações, normas e preceitos. Nesse sentido, não há vínculo legal que obrigue os fornecedores a cumprir as

\footnotetext{
37 FROTA, Mario. Auto-regulamentação: vantagens e desvantagens. Revista de Direito do Consumidor, São Paulo: Revista dos Tribunais, n. 4, p. 42-90, 1992. p. 46.

${ }^{38}$ DIAS, Lucia Ancona Lopez de Magalhães. Publicidade e direito. 2. ed. São Paulo: Revista dos Tribunais, 2013. p. 41. ${ }^{39}$ PASQUALOTTO, Adalberto. Os efeitos obrigacionais da publicidade no Código de Defesa do Consumidor. São Paulo: Revista dos Tribunais, 1997. p. 68.
}

determinações impostas pelo órgão de autorregulamentação. ${ }^{40}$

Rápido e inimigo do excesso de formalismo, o órgão autorregulamentador é um tribunal capaz de assimilar as evoluções da sociedade, refletindo os avanços, as particularidades, as nuanças locais.

\subsection{Aspectos comparados}

\subsubsection{Alemanha}

A Alemanha possui um sistema duplo de proteção à publicidade. Há requisitos legais extensos a serem observados pela indústria da publicidade, ao exercerem as comunicações comerciais de empresas, bem como, códigos de conduta criados pelo sistema de autorregulamentação.

O sistema de autorregulamentação da publicidade na Alemanha é o Deutscher Werberat ${ }^{41}$, foi criado em 1972 e visa realizar a gestão de conflitos entre os consumidores e empresas, objetivando garantir a proteção das mensagens publicitárias. O sistema de autorregulamentação opera de forma independente do governo, tendo em vista que as leis existentes nem sempre conseguem regular todas as esferas da vida do cidadão e proteger os interesses dos consumidores de forma eficaz. $\mathrm{O}$ sistema privado exerce, por exemplo, o controle de publicidade depreciativa ou discriminatória, bem como, imagens ou textos publicitários abusivos.

Dessa forma, o órgão de autorregulamentação desenvolveu códigos de conduta para a publicidade em geral, bem como,

40 RODRIGUES, Marcelo Abelha. Ensaio sobre a publicidade e o seu regime jurídico no direito brasileiro. Revista dos Tribunais, São Paulo: Revista dos Tribunais, ano 96 , v. 864 , p. 20-44, out. 2007. p. 39.

41 DEUTSCHER Werberat. Disponível em: $<$ https://www.werberat.de/>. Acesso em: 03 jan. 2016. 
outros específicos para áreas particularmente sensíveis da comunicação comercial.

As tarefas essenciais do órgão de autorregulamentação é desenvolver códigos de conduta para a publicidade e para áreas específicas, as quais remetem mais cuidado; decidir sobre as reclamações do público; informar a respeito dos códigos e da jurisprudência.

O sistema privado oferece um processo para tratamento das reclamações não burocrático, sem qualquer custo, rápido e flexível. A queixa pode ser realizada por indivíduos, grupos sociais ou entidades políticas, através do site (https://www.werberat.de/beschwerdeverfahren). Ainda, igualmente pode ser feito por telefone, fax, e-mail (werberat@werberat.de), ou usando o formulário de reclamação (http://www.werberat.de/beschwerdeformular), porém, denúncias anônimas não são tratadas.

A área de trabalho do sistema de autorregulamentação se expandiu nos mais de 40 anos de atividade, através do surgimento da televisão na década de 80 e da internet na década de 90. Atualmente todas as formas de comunicação comercial são regulamentadas pelo sistema privado. A autorregulamentação publicitária tem vasta aceitação por personagens da política, negócios, mídia, universidades e instituições da sociedade, os quais representam uma posição extremamente favorável ao trabalho desenvolvido.

\subsubsection{Argentina}

Em relação ao sistema de regulamentação publicitária presente na Argentina, Maria Cecília Mendes Borges ${ }^{42}$ afirma que há normas de autorregulamentação, possuindo um código de ética e autorregulamentação publicitária e normas

\footnotetext{
42 BORGES, Maria Cecília Mendes. Estudo comparado da legislação sobre publicidade, como aspecto da defesa do consumidor, nos países integrantes do Mercosul. Revista de
}

sobre bebidas alcoólicas. Há o estabelecimento de princípios éticos para a publicidade, como a prescrição de que seja honesta, veraz e que assuma a responsabilidade social.

$\mathrm{O}$ órgão responsável por realizar a autorregulamentação da publicidade na Argentina é o CONARP - Consejo de Autorregulación Publicitaria ${ }^{43}$, o qual foi elaborado pela Associação Argentina de Publicidade (AAP) e a Câmara Argentina de Anunciantes (CAA), para fins de especificar os princípios, valores e normas a serem observados na autorregulamentação da publicidade por anunciantes, agências de publicidade e outros meios de comunicação, garantindo um discurso comercial ético e responsável.

Os principais objetivos do referido órgão, são contribuir para uma melhor compreensão da importância da publicidade na sociedade e a responsabilidade social do seu exercício; promover a publicidade de forma digna, como positivo e determinante fator de desenvolvimento da sociedade; contribuir para a boa compreensão e cooperação entre os anunciantes, agências de publicidade e outros meios de comunicação; salvaguardar o cumprimento adequado dos padrões éticos da publicidade; intervir em conflitos que possam surgir, garantindo que a atividade publicitária seja exercida com justiça e em defesa dos princípios adotados pelo CONARP; cooperar com as autoridades que são direta ou indiretamente relacionadas com a legislação publicitária; contribuir para a formação e desenvolvimento profissional da atividade através de parceiros e trabalhar em conjunto com escolas e universidades, de forma a transmitir os estudos realizados.

O CONARP define que a publicidade deve respeitar os princípios da moralidade e da ética,

Direito do Consumidor, São Paulo, Revista dos Tribunais, ano 15, n. 60, p. 162-195, out./dez. 2006. p. 182.

${ }^{43}$ CONSEJO de Autorregulación Publicitaria. Disponível em: <http://www.conarp.org.ar/ >. Acesso em: 03 jan. 2016. 
bem como normas jurídicas, em especial o Código de Defesa do Consumidor, a lei de defesa da Concorrência, a lei do Comércio Justo, a lei de Combate ao Alcoolismo, a lei de Marcas, a lei de Proteção de Dados Pessoais, a lei de Serviços de Comunicação Audiovisual e o Código Alimentar Argentino. Em suma, o órgão estipula que tais normas devem ser observadas, uma vez que afirma que o respeito pela liberdade e a dignidade da pessoa humana deve ser o dever de todo profissional que atue direta ou indiretamente com a comunicação social.

Ainda, o código de autorregulamentação determina que os anunciantes, as agências de publicidade, os profissionais da publicidade e os responsáveis pelos meios de comunicação social devem assumir a responsabilidade social da divulgação pública de suas mensagens; igualmente devem estar cientes que a conformidade com os princípios éticos, busca preservar a publicidade para o público e à comunidade; envolver os seus esforços para ganhar a confiança da sociedade nos produtos e serviços que anunciam; devem ir contra qualquer prática de concorrência desleal e por fim, não devem incentivar a expansão e a continuidade de mensagens contrárias a este Código.

O procedimento realizado pelo CONARP, após ter sido recebida a reclamação, é analisar o caso e verificar se é contrária ou não aos princípios do Código de Autorregulamentação. Se não for contrária, a Comissão deve comunicar as conclusões ao reclamante e encerrar a ação, no prazo de 24 horas úteis.

Ou seja, apesar da Argentina não possuir uma regulamentação legal da publicidade, o órgão de autorregulamentação realiza medidas restritivas, de molde a garantir que as mensagens publicitárias estejam de acordo com padrões éticos.

\footnotetext{
44 AUSTRALIAN Association of National Advertisers. Disponível em: <http://aana.com.au/about/>. Acesso em: 03 fev. 2016.
}

\subsubsection{Austrália}

A autorregulamentação da publicidade na Austrália é realizada pelo AANA ${ }^{44}$, a associação australiana nacional dos anunciantes. $\mathrm{O}$ órgão busca garantir o direito de liberdade de expressão e simultaneamente proteger os consumidores, de molde a assegurar a realização da publicidade e de marketing de maneira responsável. Os valores da AANA são liderança, responsabilidade, parceria e integridade.

Desde a sua criação, o AANA desenvolveu e introduziu novos Códigos e alterou os códigos existentes para manter o ritmo com as rápidas mudanças na indústria de publicidade, marketing e mídia. Os referidos códigos são buscam evoluir e se adaptar para manter o ritmo com a mudança das expectativas dos consumidores.

O AANA possui um Código de Ética, o qual é o principal regulamento do sistema de autorregulamentação e é complementado por códigos de Publicidade e Marketing para crianças, de alimentos e bebidas, de questões ambientais e de Publicidade \& Marketing Código de Comunicação.

Insta esclarecer que o AANA contribui com o sistema legal de regulamentação das mensagens publicitárias, uma vez que o órgão fornece ao Governo as observações por escrito em nome da indústria, bem como, evidências detalhadas sobre o sistema privado de regulamentação da publicidade e os benefícios para os consumidores. Como parte desta colaboração, o AANA muitas vezes apresenta evidências orais às comissões competentes e procura influenciar a resposta do governo às recomendações relevantes. Ainda, o AANA contribui para outras revisões de código de regulamentação publicitária. 
Dessa forma, o órgão de autorregulamentação visa proteger os interesses dessas grandes empresas, que contribuem com um investimento publicitário estimado em mais de 14 bilhões de dólares por ano, através da criação dos códigos de autorregulamentação da publicidade.

Além disso, o órgão colabora para que seja construída a confiança do consumidor e do público, a partir de revisões periódicas de código de prática e promoção da autorregulamentação da Austrália.

A reclamação sobre o conteúdo de um anúncio publicitário pode ser realizada online ou por de uma carta (via correio ou fax) para a Advertising StandardsBureau, nível 2, 97 Northbourne Avenue, ACT TURNER 2612, bem como, através do número (02) 62629833.

\subsubsection{Canadá}

Isabella Vieira Machado Henriques 45 aborda que, no Canadá, a Advertising Standards Canada - $\mathrm{ASC}^{46}$, uma associação das indústrias deste país, com o objetivo de assegurar a integridade e viabilidade da publicidade por meio da autorregulamentação, administra o Código Canadense de Normas Publicitárias (Canadian Code of Advertising Standards).

A Advertising Standards Canada (ASC) foi criada em 1957, para fins de promover éticas publicitárias e efetuar a autorregulamentação da publicidade no Canadá. Ainda, o órgão foi fundado para garantir os interesses da indústria e do público, bem como, assegurar a integridade e a viabilidade das mensagens publicitárias.

A ASC, sendo o órgão autorregulador da publicidade no Canadá, administra o Código Canadense de Padrões Publicitários (Code), o qual é o principal instrumento da

\footnotetext{
${ }^{45}$ HENRIQUES, Isabella Vieira Machado. Publicidade abusiva dirigida à criança. Curitiba: Juruá, 2006. p. 183. 46 ADVERTISING Standards Canada. Disponível em: $<$ http://www.adstandards.com/en/ $>$. Acesso em: 03 mar. 2016.
}

autorregulamentação. O referido código define os critérios para a publicidade ser aceitável e constitui a base para a revisão e julgamento de litígios de consumo e publicidade.

O órgão em questão fornece um mecanismo de resposta dos consumidores efetivo, de molde a promover a confiança pública da publicidade. Em nome da indústria, a ASC administra um processo de reclamações dos consumidores sobre os anúncios que estão em execução na mídia canadense. Assim sendo, as reclamações que levantam um problema potencial no âmbito do Código de Padrões Publicitários no Canadá são revisadas pelo Conselho.

Através da ASC, é fornecido um mecanismo eficaz e eficiente de avaliação da publicidade em cinco categorias, quais sejam, crianças, alimentos e bebidas não alcoólicas, bebidas alcoólicas, drogas de consumo e cosméticos. Dessa forma, o mecanismo ajuda a garantir que as mensagens publicitárias obedeçam a requisitos legislativos, regulamentares e orientações setoriais específicas da indústria.

Por fim, cabe apontar que a ASC possui um procedimento destinado a resolver disputas entre os anunciantes, de acordo com as previsões do Código Canadense de Padrões Publicitários. Trata-se de um mecanismo eficaz e ágil, através do qual as disputas entre os anunciantes podem ser tratadas em um fórum confidencial e extrajudicial. O procedimento é revisado periodicamente, de molde a assegurar a sua eficácia em um cenário da publicidade que está cada vez mais competitivo.

\subsubsection{Chile}

O Código Chileno de Ética Publicitária ${ }^{47}$ tem como objetivo estabelecer as normas que

47 CONSEJO de Autorregulación Y Ética Publicitaria. Disponível em: <http://www.conar.cl/codigo-etica/>. Acesso em: 03 mar. 2016. 
devem orientar os agentes da publicidade. É baseado nas disposições do Código Internacional de Práticas de Publicidade da Câmara Internacional do Comércio de Paris, incluindo algumas ampliações, modificações e atualizações propostas pelas associações que integram o CONAR.

O Código Chileno estabelece normas de conduta ética que resguardam os interesses do público e igualmente preveem normas de sua competência. Estas regulamentações devem ser respeitadas por todos aqueles que se relacionem com a publicidade, como agências, publicitários, independente do meio de comunicação.

Importante salientar que as normas deste Código se aplicam a todas as formas de comunicação publicitária que tenham o propósito de informar ou influenciar, de maneira direta ou indireta, independentemente de quais forem os meios empregados, as opiniões e decisões das pessoas. No entanto, o Código Chileno não é aplicável à publicidade ou propaganda que expressem ideologias ou difundam doutrinas de ordem política ou religiosa, não obstantes suas regulamentações possam servir de orientação ética.

Ainda, não estão consideradas neste Código as atividades referentes às relações públicas, notas de imprensa e entrevistas, os quais são distintos da publicidade e se associam ao âmbito do periódico. Em suma, este Código de autorregulamentação é aplicado pelo Conselho de Autorregulamentação e Ética Publicitária, CONAR. Assim sendo, o Código pode ser complementado através dos pronunciamentos doutrinados emitidos pela Direção do CONAR no exercício de suas atribuições próprias.

Nesse sentido, apesar do Código ser concebido essencialmente como instrumento de autodisciplina para a atividade publicitária, também poderá ser de utilidade para as autoridades de tribunais como referência e fonte subsidiária no contexto da legislação que direta ou indiretamente afete ou seja afetada pela publicidade.

Dessa forma, considerando que a publicidade deve respeitar a legislação vigente e, em especial, os valores, direitos e princípios estabelecidos na Constituição, entre os quais tem especial relevância a família como o núcleo fundamental da sociedade; e, ainda, considerando que tendo a publicidade como fundamento básico a liberdade de expressão comercial e, por outro lado, o direito do público de estar devidamente informado, o Código Chileno declara que as mensagens publicitárias devem ser decentes, honestas e compromissadas com a verdade.

Assim, cada aviso ou manifestação publicitária deve ser preparado com responsabilidade social, por profissionais especializados que repassem informações adequadas e observem os princípios de sua competência, segundo as práticas gerais estabelecidas na sua atividade comercial. Com isso, nenhum aviso ou manifestação publicitária deve ser apresentado de forma a menosprezar a confiança do público, de molde que os produtos e serviços sejam apresentados com informações adequadas e verídicas, permitindo a livre escolha pelas pessoas.

O Código Chileno igualmente define que sendo a publicidade uma atividade orientada ao bem comum, os publicitários e as agências deverão repassar as informações de acordo com a realidade econômica, cultural e social que esteja vivendo a comunidade.

Por fim, cabe destacar que há uma especial atenção à publicidade dirigida às crianças e adolescentes, uma vez que o Regulamento define que é indispensável que sejam observadas as características psicológicas das mensagens publicitárias direcionadas a este público, diante da sua falta de experiência e capacidade de discernimento, bem como, de molde a evitar interpretações e comportamentos impróprios. $\mathrm{O}$ Código estabelece que a publicidade dirigida as 
crianças e adolescentes deve ser extremamente cuidadosa, não podendo explorar a ingenuidade, imaturidade e inexperiência.

Além disso, o Código igualmente dá uma especial atenção à publicidade de bebidas alcoólicas e tabaco. Define que bebida alcoólica é aquela classificada com tal pelas normas que se subordina a comercialização. Estabelece que as mensagens publicitárias não podem ser apresentadas nos horários dirigidos aos menores de idade, como tampouco poderá incentivar o consumo de tais produtos.

O Código Chileno igualmente afirma que nesta publicidade em especial, deve ser evitada a utilização da imagem e da voz de menores, bem como, igualmente deve ser evitada a utilização de artifícios dirigidos a este público. Defende que a publicidade de bebidas alcoólicas e tabaco não podem estimular o seu consumo excessivo ou irresponsável, ou tampouco induzir o consumo de tais produtos em locais inapropriados, ilegais ou socialmente condenáveis. Assim sendo, é expressamente definido que as mensagens publicitárias não podem mostrar os produtos como desafios a serem alcançados e também não podem demonstrar menosprezo por aqueles indivíduos que os não consomem.

\subsubsection{Espanha}

$\mathrm{Na}$ Espanha, a autorregulamentação é realizada pela Associação de Autorregulamentação da Comunicação Comercial da Espanha, designada “Associación para la Autrregulación de la Comunicación Comercial" (AUTOCONTROL) ${ }^{48}$, a qual é formada por mais de 450 membros diretos e 4.000 indiretos, ou seja, mais de $70 \%$ da representação publicitária no país.
O referido órgão atua visando garantir uma publicidade honesta e leal e não possui a pretensão de ser um substituto do controle legalmente estabelecido, mas, sim, exercer a corregulação, diferente do objetivo do sistema de autorregulamentação presente no Brasil.

O órgão AUTOCONTROL se divide em quatro setores diferentes e exerce diferentes atividades, entre elas, realizar diligência das reclamações apresentadas pelos consumidores, pelas associações de consumidores e pelas empresas; elaborar códigos deontológicos, para serem aplicados pelo Júri Publicitário; realizar serviço de consulta prévia, chamado Copy Advice, que assessora a correlação ética e legal das campanhas antes de sua emissão; e, por fim, prestar serviço de consultoria técnica e jurídica de cookies, nomeado Cookie Advice, o qual ajuda as empresas a se adequarem as novas exigências legais estabelecidas na Lei de Serviços da Sociedade de Informação e Comércio Eletrônico.

Ainda, é possível ter em mente que o sistema de autorregulamentação é gratuito, possui como objetivo garantir uma publicidade responsável e analisa as reclamações de forma ágil e eficaz através de peritos independentes, o que beneficia os consumidores. Por outro lado, a indústria é igualmente beneficiada, tendo em vista que há a diminuição de atos referentes à concorrência desleal.

O órgão de autorregulamentação tem se regido pelo cumprimento dos requisitos estabelecidos pela Lei de Concorrência Desleal, a qual fez previsão no ano de 2000 que a Direção Geral da Saúde e Proteção dos Consumidores da Comissão Europeia, em parceria com o governo espanhol, incluiu o AUTOCONTROL à "rede europeia de órgãos de solução extrajudicial de litígio com os consumidores" que é gerida,

\footnotetext{
48 ASOCIACIÓN para la Autorregulación de la Comunicación Comercial. Disponível em: $<\mathrm{http}$ ://www.autocontrol.es/>. Acesso em: 03 abr. 2016.
} 
atualmente, pela "direção geral de justiça e consumidores da Comissão Européia".

\subsubsection{Estados Unidos}

John E. Villafranco e Katherine Riley lecionam que, nos Estados Unidos, o principal órgão responsável pela autorregulamentação da publicidade é a National Advertising Division (NAD); porém, cabe ao Advertising SelfRegulatory Council (ASRC) estabelecer as políticas gerais e os procedimentos para a autorregulamentação da indústria.

A NAD é administrada pelo Council of Better Business Bureaus (CBBB). Além destes órgãos, o sistema de autorregulamentação publicitária ainda engloba a Children's Advertising Review Unit (CARU), responsável pela autorregulamentação da publicidade infantil, e o Electronic Retailing Self-Regulation Program (ERSP), encarregado de autorregular a publicidade de anunciantes de varejo eletrônico.

Criada em 1971, a NAD surgiu com o intuito de promover a verdade e a exatidão na publicidade norte-americana. $\mathrm{O}$ órgão recebe reclamações de consumidores, anunciantes e agências, e também pode iniciar investigações de ofício, através da monitoração contínua que exerce sobre a indústria. A NAD ocupa-se apenas de anúncios veiculados nacionalmente ou com grande exposição regional. Tratando-se de anúncio divulgado somente em nível local, a análise quanto às possíveis infrações éticas cabe à sessão do CBBB mais próxima do anunciante.

Reclamações referentes ao desempenho do produto, à competitividade do produto e todos os tipos de afirmações científicas e técnicas na publicidade nacional são exemplos de casos aceitos pela NAD. Ou seja, o órgão não é destinado a abordar questões morais sobre os produtos oferecidos para venda ou propaganda política.

A missão da NAD é revisar a publicidade nacional para alcançar veracidade e exatidão, de molde a gerar a confiança do público, através da credibilidade da propaganda. A política e os procedimentos da NAD são estabelecidos pelo Conselho de Autorregulamentação Publicitária (ASRC). A NAD estabelece uma alternativa para solucionar o impasse, mais barata do que os litígios perante os Tribunais. Ainda, o processo que tramita perante o NAD é mais rápido $\mathrm{e}$ privado, uma vez que o órgão julga no prazo de 60 dias úteis e, ainda, em virtude de todos os dados constantes na demanda permanecerem confidenciais. Por fim, cabe salientar que a NAD resolve as disputas de forma justa e eficaz, tendo em vista que utiliza uma forma híbrida de resolução de litígios, com a estreita colaboração do conselho interno, executivos de marketing, departamento de pesquisa e desenvolvimento, bem como, consultores externos para decidir se as alegações foram comprovadas.

Assim sendo, a NAD ganhou o respeito dos consumidores e outros órgãos reguladores, uma vez que fornece um mecanismo de autorregulamentação eficaz e de sucesso.

\subsubsection{Itália}

A Itália possui tanto regulamentação legal quanto autorregulamentação. No âmbito judicial e administrativo, o controle, é feito pelas cortes civis, o Comissário de Mercado e Concorrência e a Autoridade de Comunicação.

Por sua vez, a autorregulamentação é feita pelo Instituto para Autorregulamentação da Publicidade (IAP) ${ }^{49}$, o qual conta com a participação de grande parte das agências de publicidade, publicitários e companhias de mídia. O IAP preza pela garantia de que todas as

\footnotetext{
${ }^{49}$ ISTITUTO dell'Autodisciplina Pubblicitaria. Disponível em: <http://www.iap.it/>. Acesso em: 03 maio 2016.
} 
propagandas sejam honestas, confiáveis e forneçam aos consumidores informações que estejam de acordo com o Código de Autorregulamentação de Publicidade (CAP). Os membros do sistema privado de regulamentação da publicidade julgam com total independência de imparcialidade.

O sistema de autorregulamentação na Itália deve obrigatoriamente ser observado pelas agências de publicidade, publicitários e por todas as empresas que investem na comunicação comercial. Dessa forma, a maior parte da comunicação comercial italiana respeita as normas privadas de regulamentação da publicidade.

As principais características do IAP é a rapidez, uma vez que as reclamações são resolvidas no prazo máximo de 12 dias úteis; a independência e a imparcialidade, tendo em vista que o órgão não é vinculado ao sistema de fiscalização estatal; a eficácia, eis que decidida a reclamação pelo Conselho, a mensagem publicitária pode ser imediatamente cassada; a gratuidade e o fácil acesso pelos cidadãos, uma vez que qualquer pessoa pode realizar denúncias online, garantindo a proteção do consumidor.

Ainda, o órgão assegura a transparência das decisões, tendo em vista que são publicidades no próprio site do IAP, bem como, grande flexibilidade, uma vez que as regras do Código são constantemente atualizadas, diante da rápida evolução da comunicação. Por fim, o IAP se caracteriza por ser um sistema preventivo, eis que não apenas bloqueia a publicidade indevida, mas realizada ações preventivas de controle das mensagens publicitárias.

Ainda, o órgão de autorregulamentação igualmente é reconhecido por muitas decisões dos tribunais italianos. O Supremo Tribunal de Justiça apontou que as regras estabelecidas no Código do
IAP viabilizam critérios de avaliação corretos, os quais adaptam $\mathrm{o}$ princípio da integridade profissional à evolução das necessidades do negócio.

\subsubsection{França}

$\mathrm{Na}$ França, o organismo de regulação é exercido pelo Conséil Supérieur de l'Audiovisuel (CSA), cuja competência, em caso de descumprimento da lei, vai desde aplicação de multa até a dissolução da emissora.

Ainda, a autorregulamentação da publicidade é realizada pela Autorité de Régulatiom Professionelle de La Publicité (ARPP) ${ }^{50}$, a qual tem como missão agir em busca de uma solução justa e verdadeira, garantindo o interesse dos consumidores, do público e dos profissionais da área da publicidade.

Independente do governo, a ARPP é administrada por anunciantes, agências e meios de comunicação, os quais são os responsáveis pela produção e difusão da Publicidade. Atuando desde 2008, é um sistema mais colaborativo e mais aberto à sociedade civil e dos consumidores.

A ARPP possui órgãos associados, como o Conselho de Ética da Publicidade (CEP), o qual auxilia analisando antecipadamente a ética, o conteúdo da publicidade, a sua distribuição e a sua aceitabilidade por parte da sociedade. Ainda, o Conselho Conjunto para Publicidade (PPC) atua como um órgão consultivo, alertando a ARPP sobre as expectativas de diversas associações ou organizações a respeito do conteúdo da publicidade e sua regulamentação profissional, bem como, contribuindo para o debate sobre a elaboração das regras profissionais da publicidade.

Por fim, o Júri de Ética da Publicidade (JDP) igualmente auxilia a ARPP, realizando

50 AUTORITÉ de Régulation Professionnelle de La Publicité. Disponível em: <http://www.arpp-pub.org/>. Acesso em: 03 maio 2016. 
pronunciamentos públicos sobre as denúncias realizadas contra uma propaganda ou campanha.

A ARPP objetiva conciliar a liberdade de expressão e o respeito com os consumidores comerciais, gerando o equilíbrio entre a publicidade e a responsabilidade comercial. O órgão busca desenvolver regras para a regulamentação da publicidade, através de medidas preventivas, consultas com a sociedade $\mathrm{e}$ prestações de contas e não apenas a mera aplicação de leis já existentes.

Através de medidas preventivas, a ARPP analisa a publicidade antes de ser transmitida, devendo emitir um parecer considerando a propaganda apta a ser divulgada, apontando que deve sofrer alguma alteração ou, ainda, indicando que não deve ser transmitida. Ainda, mesmo após a publicidade ser veiculada, a ARPP também pode intervir, assim como o público, o qual pode ingressar no Júri de Ética da Publicidade, para ser analisado o mérito da denúncia.

Em suma, a fim de desempenhar a correta regulamentação da publicidade, a ARPP permanece sempre atenta às demandas $\mathrm{e}$ preocupações da sociedade, realizando ações em prol de uma solução justa e ética, para fins de garantir a divulgação das mensagens publicitárias, de acordo com as regras estabelecidas, garantindo $\mathrm{o}$ benefício dos profissionais, dos consumidores e do público.

\subsubsection{Portugal}

Em Portugal, é expressamente previsto na sua Constituição que a publicidade deve ser disciplinada por lei, sendo proibida qualquer mensagem publicitária oculta, indireta ou dolosa e, ainda, que os consumidores possuem direito à informação. Nesse sentido, a intervenção do Direito na atividade publicitária objetiva a proteção dos interesses dos consumidores e, simultaneamente, o interesse das empresas, de molde a garantir uma concorrência leal.

$$
\text { A Entidade Reguladora para a }
$$
Comunicação Social (ERC) ${ }^{51}$ foi criada em novembro de 2005, e é a entidade responsável por efetuar a regularização e supervisão de todas as entidades sob jurisdição do Estado Português que atuem no ramo da comunicação social.

Assim sendo, na esfera da autorregulamentação, a ERC elabora códigos e acordos distribuídos no ramo das atividades relacionadas ao jornal, televisão e publicidade. Por outro lado, no âmbito da corregulamentação, o órgão atua através de protocolos e acordos com foco na comunicação comercial e televisão, visando a proteção dos menores e da dignidade humana.

Dessa forma, o Instituto Civil da Autodisciplina da Comunicação (ICAP) foi criado no ano de 1991, com o principal objetivo de implementar em Portugal o sistema de autorregulamentação da publicidade. $\mathrm{O}$ órgão não possui fins lucrativos e é constituído por anunciantes, agências de publicidade e meios de comunicação. Busca a defesa dos princípios éticos-deontológicos da comunicação e atividade publicitárias.

O ICAP tem como suas atribuições promover a suspensão imediata da publicidade que se revele lesiva dos direitos dos profissionais ou do público em geral; elaborar, estabelecer e implementar normas e códigos éticos deontológicos; contribuir para a elaboração e aperfeiçoamento da legislação; promover um espírito de entendimento e cooperação, de molde a dirimir eventuais conflitos e prestar informações.

Dessa maneira, o referido sistema de autorregulamentação foi criado pela própria

\footnotetext{
${ }^{51}$ ENTIDADE Reguladora para a Comunicação Social. Disponível em: <http://www.erc.pt/>. Acesso em: 03 jun. 2016.
} 
indústria e é de adesão voluntária por parte dos seus profissionais, anunciantes, agências e meios, o qual tem como objetivo assegurar a rápida e eficaz observância das regras da leal concorrência e dos princípios da legalidade, decência, honestidade e veracidade, na comunicação publicitária, contribuindo para ser efetivada a responsabilidade social.

Nesse sentido, a autorregulamentação pressupõe condições prévias para a obediência voluntária à contenção auto imposta, estando à disposição do órgão em questão, a realização de sanções eficazes. Exemplos são a imposição de autorização prévia obrigatória, por parte do órgão de autorregulamentação, para futuros anúncios do anunciante infrator; recusa por parte dos meios de comunicação em publicar anúncios contra os quais tenha sido apresentada uma queixa e à qual o órgão autorregulamentador tenha dado razão; retirada de privilégios comerciais, tais como tarifas de correio especiais; e, por fim, como sanção extrema, na hipótese em que tudo o mais tenha falhado, é realizado o encaminhamento do assunto para a autoridade legal competente, a qual poderá instaurar uma ação legal contra o infrator.

\subsubsection{Reino Unido}

Monlee Lee e Carla Johnson ${ }^{52}$ afirmam, por sua vez, que, no Reino Unido, o regime de regulamentação da publicidade é uma combinação única de case law, direito positivado e autorregulamentação, sendo diferente dos demais sistemas regulatórios existentes nos Estados Unidos e nos países da Europa continental. Mencionam os doutrinadores que tais divergências derivam da ausência de leis escritas que proíbam propaganda enganosa e desleal, bem como do papel de destaque desempenhado pelo órgão de autorregulamentação no controle de abusos específicos.

No Reino Unido, a Advertising Standards Authority (ASA) $)^{53}$ age para resolver reclamações sobre a publicidade em meios de comunicação, incluindo televisão, rádio, imprensa, cartazes, marketing direto e publicidade online.

Há juristas que defendem que o sistema britânico é o modelo mais bem-acabado de autorregulamentação publicitária no mundo, tendo servido como principal referência para a criação do brasileiro. Mantido por uma taxa de $0.1 \%$ cobrada sobre o preço de venda dos espaços de mídia publicitária, a Advertising Standards Authority (ASA) é a maior, mais ativa, e mais rica autoridade de autorregulamentação da propaganda no mundo. A absoluta maioria das reclamações referentes ao conteúdo de anúncios publicitários é direcionada, em primeira instância à ASA. Nesse sentido, a interferência do Estado nesses casos é a exceção e ocorre apenas quando a violação ultrapassa a esfera de autuação da autorregulamentação. ${ }^{54}$

O CAP, criado em 1961, é o órgão responsável pela redação e atualização da versão britânica do nosso Código de Autorregulamentação Publicitária: o British Code and Advertising, Sales Promotion and Direct Marketing. Os princípios básicos que norteiam esse documento são os de que a publicidade deverá ser, legal, decente, honesta e verdadeira; elaborada com um senso de responsabilidade para com os consumidores e a sociedade; condizente com os princípios da concorrência leal.

Barbara Mueller, por sua vez, leciona que no Reino Unido as consequências para os anunciantes que não observarem as regras de autorregulamentação podem ser muito severas. Em casos extremos, o anunciante pode até ser
52 LEE, Monlee; JOHNSON, Carla. Principles of advertising: a global perspective. New York: The Haworth Press, 2005. p. 62.
53 ADVERTISING Standards Authority. Disponível em: $<$ https://www.asa.org.uk/>. Acesso em: 03 jul. 2016.

${ }^{54}$ LEE; JOHNSON, op. cit., p. 62. 
proibido de veicular anúncios em qualquer mídia durante certo período de tempo. ${ }^{55}$

Ao contrário do CONAR, a ASA tem a prerrogativa de vetar previamente a veiculação de propagandas. Vinte e cinco categorias de anúncios estão sujeitas a este controle prévio, como propagandas religiosas, de bebidas alcoólicas, relacionadas à saúde, e aquelas narradas por crianças. A grande maioria dos anúncios de televisão e spots de rádio no Reino Unido, por sinal, passam por uma "triagem" pela ASA antes de serem veiculados. ${ }^{56}$

Assim como ocorre na autorregulamentação brasileira, uma reclamação de um único consumidor já é suficiente para que a ASA dê início ao processo de julgamento de um anúncio. É importante observar que a ASA foi uma das pioneiras na implementação de restrições às propagandas de cigarro no mundo, tendo proibido, desde 1994, o uso do humor nos anúncios e a colocação de outdoors de empresas de cigarro a menos de duzentos metros de escolas. $^{57}$

\section{CONCLUSÃO}

Após a realização do artigo jurídico, foi possível perceber que de um lado a publicidade é de extrema relevância, uma vez que permeia e contribui de modo substancial para o dinamismo das relações de consumo da atualidade; por outro lado, o direito à publicidade não constitui um direito absoluto, motivo pelo qual, precisa ser regulamentado, para fins de evitar arbitrariedades por parte dos anunciantes e publicitários. Assim sendo, embora a publicidade seja uma atividade constitucionalmente prevista, deve sofrer

\footnotetext{
55 MUELLER, Barbara. Dynamics of International Advertising: Theoretical and Practical Perspectives. New York: Peter Lang Publishing, Inc., 2011. p. 312.

56 SHAH, Kruti; D'SOUZA, Alan. Advertising \& Promotions: an IMC perspective. New Dheli: Tata McGraw-Hill, 2009. p. 918.
}

limitações em respeito a outros direitos tutelados na Constituição Federal.

Em verdade, a publicidade é um tema que desafia o legislador, apresentando grandes riscos para o consumidor, pois é de difícil harmonização o desejo de sedução e a necessidade de informação adequada, respeitando certas regras e valores que dão norte à convivência social, inspirando o consumo, mas não o consumismo.

Nesse sentido, visando verificar os meios de restrição das mensagens publicitárias e, dessa forma, realizando a análise dos órgãos de regulamentação da publicidade nacional e estrangeiros, foi possível concluir que há uma série de aspectos interessantes, os quais merecem ser devidamente considerados, tendo em vista que tais institutos possuem relevante valor jurídico e social, por garantirem o controle da publicidade e efetuarem a proteção dos interesses difusos dos consumidores.

Após o estudo mais aprofundado dos modelos público e privado de controle das mensagens publicitárias, foi possível constatar que sistema de autorregulamentação é mostra bastante interessante e merece ser considerado, em virtude de ser rápido e evitar maiores formalidades.

O modelo privado de controle da publicidade viabiliza a proteção das empresas em um mercado concorrencial, bem como assegura os direitos dos consumidores, sendo capaz de assimilar as evoluções da sociedade.

No entanto, especificamente no Brasil, o órgão regulamentador não possui uma real eficácia, uma vez que as suas decisões são de cumprimento espontâneo e não possuem caráter coercitivo.

57 LEE, Monlee; JOHNSON, Carla. Principles of advertising: a global perspective. New York: The Haworth Press, 2005. p. 63. 
Assim sendo, após a análise dos aspectos do direito comparado, é possível concluir que a autorregulamentação publicitária exercida pela França, através do Autorité de Régulatiom Professionelle de La Publicité (ARPP), é o modelo mais completo e eficaz, uma vez que estipula medidas preventivas, para que as mensagens publicitárias sequer sejam transmitidas na hipótese de estarem em desconformidade com as exigências e, ainda, igualmente prevê consultas com a sociedade e prestações de contas, realizando não apenas a mera aplicação de leis já existentes. Nesse sentido, é possível afirmar que a liberdade de expressão e o respeito com os consumidores comerciais são conciliados, gerando o equilíbrio entre a publicidade e a responsabilidade comercial.

\section{REFERÊNCIAS}

ADVERTISING Standards Authority. Disponível em: $<$ https://www.asa.org.uk/>. Acesso em: 03 jul. 2016.

ADVERTISING Standards Canada. Disponível em: <http://www.adstandards.com/en/>. Acesso em: 03 mar. 2016.

ASOCIACIÓN para la Autorregulación de la Comunicación Comercial. Disponível em: $<$ http://www.autocontrol.es/>. Acesso em: 03 abr. 2016.

AUSTRALIAN Association of National Advertisers. Disponível em: <http://aana.com.au/about/>. Acesso em: 03 fev. 2016.

AUTORITÉ de Régulation Professionnelle de La Publicité. Disponível em: <http://www.arpppub.org/>. Acesso em: 03 mai. 2016.

BENJAMIN, Antônio Herman Vasconcellos e. O controle jurídico da publicidade. Revista de Direito do Consumidor, São Paulo, Revista dos Tribunais, n. 9, p. 25-57, jan./mar. 1994.

BORGES, Maria Cecília Mendes. Estudo comparado da legislação sobre publicidade, como aspecto da defesa do consumidor, nos países integrantes do Mercosul. Revista de Direito do Consumidor, São Paulo, Revista dos Tribunais, ano 15, n. 60, p. 162-195, out./dez. 2006.

BRITTO, Igor Rodrigues. Liberdade de expressão comercial, só se for nos Estados Unidos. Revista Jurídica Consulex, Rio de Janeiro, v. 15, n. 349, p. 28-31, jul. 2011.

CARVALHO, Diógenes Faria de. A proteção do consumidor-criança frente à publicidade no Brasil. Revista de Direito do Consumidor, São Paulo, Revista dos Tribunais, n. 94, p. 181-211, 2014.

CHAISE, Valéria Falcão. A publicidade em face do Código de Defesa do Consumidor. São Paulo: Saraiva, 2011.

CÓDIGO Brasileiro de Autorregulamentação Publicitária. Disponível em: $<$ http://www.conar.org.br/codigo/codigo.php>. Acesso em: 23 out. 2015. 
CONSEJO de Autorregulación Publicitaria. Disponível em: <http://www.conarp.org.ar/ > . Acesso em: 03 jan. 2016.

CONSEJO de Autorregulación y Ética Publicitaria. Disponível em: <http://www.conar.cl/codigoetica/>. Acesso em: 03 mar. 2016.

CONSELHO Nacional de Autorregulamentação Publicitária. Disponível em: $<$ http://www.conar.org.br/>. Acesso em: 03 fev. 2016.

CRAVO, Daniela Copetti. A tutela do consumidor através da livre-concorrência: a busca por um efetivo direito de escolha. Revista Magister de Direito Empresarial, Concorrencial e do Consumidor, Porto Alegre, v. 49, p. 66-81, fev./mar. 2013.

DEUTSCHER Werberat. Disponível em: <https://www.werberat.de/>. Acesso em: 03 jan. 2016.

DIAS, Lucia Ancona Lopez de Magalhães. Publicidade e direito. 2. ed. São Paulo: Revista dos Tribunais, 2013.

DINIZ, Catarina Fernandes. A influência dos estímulos não-consciencializados no comportamento do consumidor. Tese para a Licenciatura em Comunicação Empresarial, ISCEM, Lisboa, 1999.

ENTIDADE Reguladora para a Comunicação Social. Disponível em: <http://www.erc.pt/>. Acesso em: 03 jun. 2016.

FACCHINI NETO, Eugênio. A função social do direito privado. Revista da Ajuris, Porto Alegre, n. 105, p. 154-155, 2007.

FROTA, Mario. Auto-regulamentação: vantagens e desvantagens. Revista de Direito do Consumidor, São Paulo, Revista dos Tribunais, n. 4, p. 42-90, 1992.

HENRIQUES, Isabella Vieira Machado. Publicidade abusiva dirigida à criança. Curitiba: Juruá, 2006.

ISTITUTO dell'Autodisciplina Pubblicitaria. Disponível em: $<$ http://www.iap.it/>. Acesso em: 03 mai. 2016.

JACOBINA, Paulo Vasconcelos. A publicidade no direito do consumidor. Rio de Janeiro: Forense, 2012.

LEE, Monlee; JOHNSON, Carla. Principles of advertising: a global perspective. New York: The Haworth Press, 2005.

LUHMANN, Niklas. La realidad de los medios de massas. Tradução para espanhol de Javier Torres Nafarrate. Barcelona: Anthropos, México: Universidad Iberoamericana, 2007.

MARQUES NETO, Floriano Azevedo. Regulação econômica e suas modalidades. Revista de Direito Público da Economia, Belo Horizonte, ano 7, n. 28, p. 27-42, out./dez. 2009.

MARQUES, Cláudia Lima. Contratos no Código de Defesa do Consumidor. 3. ed. São Paulo: Revista dos Tribunais, 1998. 
MARTINEZ, Sergio Rodrigo. O ambiente conceitual da publicidade de consumo e de seu controle no Brasil. Revista de Direito do Consumidor, São Paulo, Revista dos Tribunais, n. 58, p. 223-255, abr./jun. 2006.

MIRAGEM, Bruno. Direito do consumidor. São Paulo: Revista dos Tribunais, 2008.

MOMBERGER, Frisque Noemí. A publicidade dirigida às crianças e adolescentes: regulamentações e restrições. Porto Alegre: Memória Jurídica, 2002.

MUELLER, Barbara. Dynamics of International Advertising: Theoretical and Practical Perspectives. New York: Peter Lang Publishing, Inc., 2011.

NATIONALAdvertising Division. Disponível em: $<$ https://www.bbb.org/council/the-national-partnerprogram/national-advertising-review-services/national-advertising-division/>. Acesso em: 03 abr. 2016.

NUNES JR., Vidal Serrano. Limites à publicidade comercial e proteção de direitos fundamentais. Revista de Direito Constitucional e Internacional, São Paulo, Revista dos Tribunais, ano 16, n. 63, p. 270-283, abr./jun. 2008. p. 282.

NUNES, Rizzatto. Publicidade \& Consumo. Revista Jurídica Consulex: Rio de Janeiro, v. 15, n. 349, p. 24-27, jul. 2011.

PASQUALOTTO, Adalberto. Os efeitos obrigacionais da publicidade no Código de Defesa do Consumidor. São Paulo: Revista dos Tribunais, 1997.

PAVANI, Letícia Lourenço. Publicidade de serviços sexuais e implicações no âmbito da dignidade da pessoa humana e da proteção à infância. Revista de Direito Social, São Paulo, Notadez, ano VIII, n. 30, p. 93-104, abr./jun. 2008.

PFEIFFER, Roberto Augusto Castellanos. Tutela coletiva da livre concorrência. Revista de Direito do Consumidor, São Paulo, Revista dos Tribunais, n. 49, p. 15-23, 2004.

RODRIGUES, Marcelo Abelha. Ensaio sobre a publicidade e o seu regime jurídico no direito brasileiro. Revista dos Tribunais, São Paulo, Revista dos Tribunais, ano 96, v. 864, p. 20-44, out. 2007.

SANT'ANNA, Armando. Propaganda: teoria, técnica e prática. 3. ed. São Paulo, Pioneira, 1981.

SCHMITT, Cristiano Heineck. A proteção do interesse do consumidor por meio da garantia à liberdade de concorrência. Revista dos Tribunais, São Paulo, Revista dos Tribunais, ano 98, v. 880, p. 9-32, fev. 2009.

SHAH, Kruti; D'SOUZA, Alan. Advertising \& Promotions: an IMC perspective. New Dheli: Tata McGraw-Hill, 2009.

SIANO, James Alberto. A publicidade como forma de liberdade de expressão. Revista dos Juizados Especiais, São Paulo, Fiuza, ano 9, v. 33, p. 11-37, jul./set. 2004.

Recebido em: 30/09/2016

Aceito em: 21/01/2017 
